\title{
Stability and change over 67 years - the community of Heteroptera as caught in a light-trap at Rothamsted, UK
}

\author{
T. Richard E. SOUTHWOOD ${ }^{1}$, Peter A. HENDERSON ${ }^{2}$ and IAN P. WOIWOD 3 \\ ${ }^{1}$ Department of Zoology, University of Oxford, South Parks Road, Oxford OX1 3PS, UK; \\ e-mail: Richard.Southwood@zoology.ox.ac.uk \\ ${ }^{2}$ Pisces Conservation Ltd, IRC House, Pennington, Lymington, Hampshire SO41 8GN, UK; e-mail: Peter@irchouse.demon.co.uk \\ ${ }^{3}$ Plant and Invertebrate Ecology Division, Rothamsted Research, Harpenden, Hertfordshire AL5 2JQ, UK; \\ e-mail: Ian.woiwod@bbscr.ac.uk
}

Key words. Heteroptera, Lepidoptera, stability, environmental change, farmland biodiversity, light-traps, diversity

\begin{abstract}
The Heteroptera, principally mirids, collected in a light-trap run on a field margin at Rothamsted Experimental Station for various periods between 1933 and 2000, have been identified, and the catches analysed to show the extent of change and stability in the community.

2. Trap catch, both in terms of individuals and species, was correlated with maximum daily temperature.

3. $\alpha$-diversity showed a U-shaped curve over the period. The dip may have been associated with pesticide use, although a lack of days with high maximum temperatures cannot be ruled out.

4. By the late $1990 \mathrm{~s}, \alpha$-diversity had again reached a peak (Fisher's $=11$ ), comparable to that in the $1930 \mathrm{~s}$.

5 . However, the change in the composition of the community over the whole period ( $\beta$-diversity) was significant, the index of difference being 0.66 on a scale where 0 is no change in composition or relative abundance and 1 no species in common.

6. The value of $\beta$-diversity was highest in the water bugs, which disappeared altogether. Categorising the others by host plant type, the greatest change over time was in those associated with perennial herbs. There were decreasing differences in tree-dwellers and grassland species respectively, and the least change was in the community associated with annual plants (arable weeds).

7. Changes in the abundance of Heteroptera since 1933 follow closely those of the macrolepidoptera from the same samples. However changes in diversity show very different patterns, with moth diversity continuing to decline since 1960 in contrast to the increases apparent from the Heteroptera data.
\end{abstract}

\section{INTRODUCTION}

There is a widespread interest in the extent of change in the composition and abundance of flora and fauna over the last century, particularly in the UK (Hawksworth, 2001). Of the numerous factors both natural and anthropogenic that could lead to changes in the community, the three considered in this study to have the most potential to have an appreciable influence are land management, the widespread use of pesticides, and climatic variation. Several studies have shown changes of distribution and abundance in what may be termed rare or local species, but insects have seldom been sampled consistently over a long period, even at a single site, to provide a quantitative picture of long-term changes for a major taxon. The most extensive data of this type have been collected in a sister study of macrolepidoptera taken in the same light-trap at the side of an arable field at Rothamsted, over the same time period (Taylor et al., 1978; Taylor, 1986; Woiwod \& Thomas, 1993; Woiwod \& Harrington, 1994; Riley 1999).

This paper analyses the Heteroptera records, an ecologically important and diverse group of insects where the adults live mostly on the same host plants as the larvae and where flight may not be a regular feature of adult life. Changes in diversity and abundance of the Heteroptera are then compared and contrasted with the changes of the moth populations at the same site.

\section{MATERIAL AND METHODS}

The catches were made in a standard Rothamsted Light Trap (Williams, 1939) placed at the margin of an arable field, Barnfield, at Rothamsted Experimental Station, about $35 \mathrm{~km}$ northwest of London (Southwood, 1960; Riley, 1999). The trap was run from 1933-1936 and the Heteroptera for that period were identified by Thomas (1938), and again from 1946-1949 and in 1956, the Heteroptera being recorded by Southwood (1960). In 1956 the trap had a 125 Watt MV bulb and was a short distance from the previous site; the analyses of Taylor \& French (1974) and Intachat \& Woiwod (1999) indicate that these changes would not have been expected to affect greatly the diversity of the catch. The trap was operated again in its original position from 1960, when it became Rothamsted Insect Survey's first light-trap site, using the original 200 Watt tungsten bulb, but the full catches have only been retained routinely since 1976 . Dr. B. S. Nau identified material from 1960 , which was kept, and has kindly given us these data and those for 1980 and 1985. The material from 17 other annual catches between 1976 and 2000 has been identified by one of us (TRES), but Heteroptera were extracted only from catches between June and September inclusive. These would have comprised the great majority of the year's catch (during 1946-49 only $0.7 \%$ of the total catch was trapped in the months excluded in the recent work). Identifications conformed to the taxonomy applicable in the 1930s. This was so that the results could be compared directly with those of 


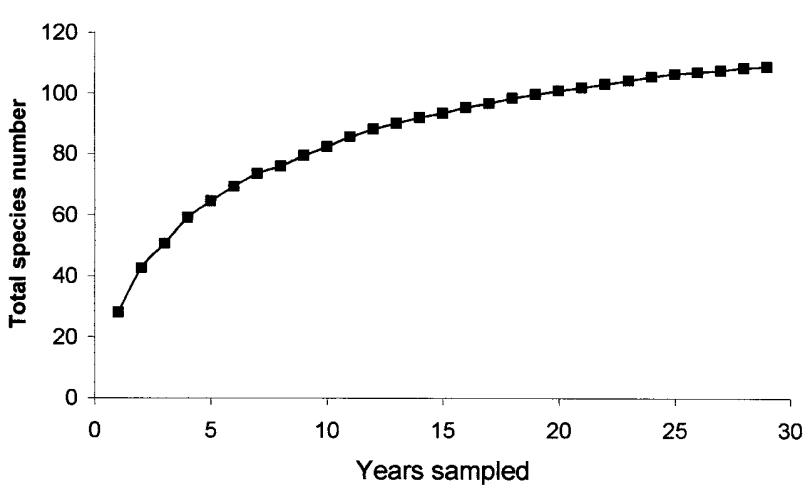

Fig. 1. Species accumulation curve for the Heteroptera recorded from the Rothamsted light-trap between 1933 and 2000. To show the effect of sampling effort without the influence of year order the average of 10 randomisations of sample sequence was calculated.

ApPEndix 1. The most abundant species of Heteroptera taken in the light trap over the 30 years studied over the period 1933-2000 together with the number of years in which each species was caught.

\begin{tabular}{|c|c|c|}
\hline Species & $\begin{array}{c}\text { Total } \\
\text { individuals }\end{array}$ & $\begin{array}{l}\text { Years } \\
\text { recorded }\end{array}$ \\
\hline Lygus rugulipennis Poppius & 4484 & 30 \\
\hline Adelphocoris lineolatus (Goeze) & 865 & 27 \\
\hline Orthotylus flavosparsus (Sahlberg) & 625 & 23 \\
\hline Megalocoleus molliculus (Fallen) & 482 & 20 \\
\hline $\begin{array}{l}\text { Trigonotylus ruficornis } \\
\text { (Geoffroy in Fourcroy) }\end{array}$ & 357 & 24 \\
\hline Phytocoris varipes Boheman & 349 & 26 \\
\hline Blepharidopterus angulatus (Fallen) & 323 & 26 \\
\hline Stenotus binotatus (Fabricius) & 303 & 28 \\
\hline Stenodema calcaratum (Fallen) & 282 & 28 \\
\hline Calocoris norvegicus (Gmelin) & 276 & 22 \\
\hline Orthops kalmi (L.) & 235 & 10 \\
\hline Asciodema obsoletum (Fieber) & 229 & 19 \\
\hline Orthops cervinus (Herrich-Schaffer) & 137 & 27 \\
\hline Orthotylus marginalis Reuter & 136 & 22 \\
\hline Phytocoris tiliae (Fabricius) & 131 & 22 \\
\hline Psallus varians (Herrich-Schaffer) & 121 & 21 \\
\hline Orthotylus virescens (Douglas and Scott) & 112 & 21 \\
\hline Nabis ferus (L.) & 99 & 13 \\
\hline Orthotylus nassatus (Fabricius) & 68 & 15 \\
\hline Psallus perrisi (Mulsant and Rey) & 52 & 18 \\
\hline Lygocoris viridis (Fallen) & 45 & 15 \\
\hline Lygocoris pabulinus (L.) & 44 & 11 \\
\hline Acanthosoma haemorrhoidale (L.) & 38 & 12 \\
\hline Macrotylus solitarius (Meyer-Dur) & 37 & 13 \\
\hline Psallus obscurellus (Fallen) & 37 & 7 \\
\hline Atractotomus magnicornis (Fallen) & 36 & 11 \\
\hline Orthotylus ochrotrichus Fieber & 32 & 14 \\
\hline Plagiognathus arbustorum (Fabricius) & 32 & 11 \\
\hline Psallus falleni Reuter & 32 & 10 \\
\hline Macrolophus nubilis (Herrich-Schaffer) & 32 & 8 \\
\hline
\end{tabular}

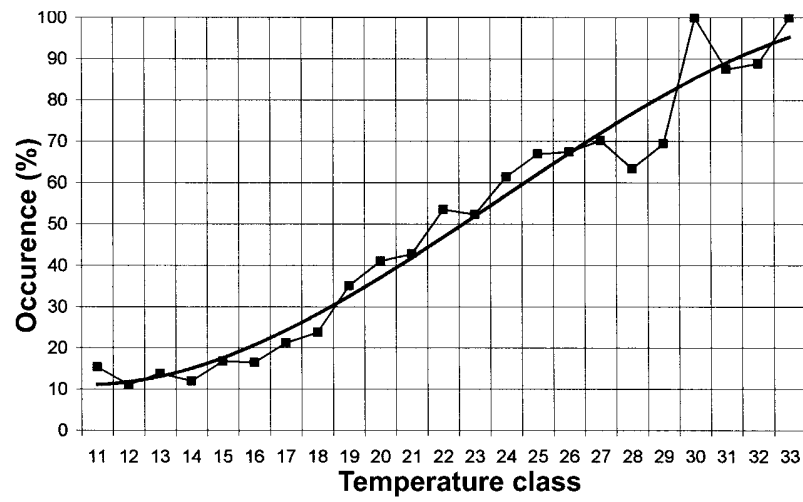

Fig. 2. The relationship between maximum daily temperature and flight for Heteroptera from Rothamsted light-trap data. For each $1^{\circ} \mathrm{C}$ temperature class the proportion of days on which at least one specimen of Heteropera was caught was plotted against the maximum daily temperature. The calculations were made for all available years from 1933 to 2000 for the months of June to September. No clear temperature threshold was observed and a $3^{\text {rd }}$ order polynomial curve was fitted to the data by regression.

Thomas (1938). A total of 10,672 individual insects, representing 118 species, form this data set. The full information for the post-war years is held by the Rothamsted Insect Survey; the more abundant species are listed in Appendix 1.

The species accumulation curve for the whole period (Fig. 1) shows that the species pool has been virtually exhausted (Southwood 1996) and therefore the catches are a valid representation of the community. The slow, almost linear increase in species number after about 15 years of sampling is a typical feature of long-term community data and reflects the gradual capture of wanderers from different habitats and rare migrants.

\section{THE EFFECT OF TEMPERATURE ON FLIGHT}

Heteroptera frequently undertake most of their trivial movements by walking. Whether this is replaced by flight, with the potential for migration, seems to be very dependent on temperature, records of which are readily available online from the Rothamsted site for all years but 1948 (The British Atmospheric Data Centre at http://www.badc.rl.ac.uk). If days are grouped by their maximum daily temperature, the proportion in which flight occurred (at least one specimen was caught) gives a significant fit to a logistic regression (Fig. 2) and there is no step change that would indicate a threshold common for the whole group (Taylor, 1963). When a similar analysis is undertaken for the most abundant species, Lygus rugulipennis Poppius, again there is no step change, so it seems that in practice this may not be a useful concept for trap catches of mirids. There is, however, a highly significant correlation between the annual species richness of the catch and summer temperature as measured by the number of days above $25^{\circ} \mathrm{C}\left(\mathrm{r}^{2}=0.45, \mathrm{P}\right.$ $<0.00001$ ) (Fig. 3) so that changes over time in species richness in trap catches could be due to changes in weather rather than community make-up. Although some of this relationship might be due to an increase in numbers of individuals, and hence species, at higher temperatures there is still a significant relationship $\left(\mathrm{r}^{2}=0.15, \mathrm{P}<\right.$ 


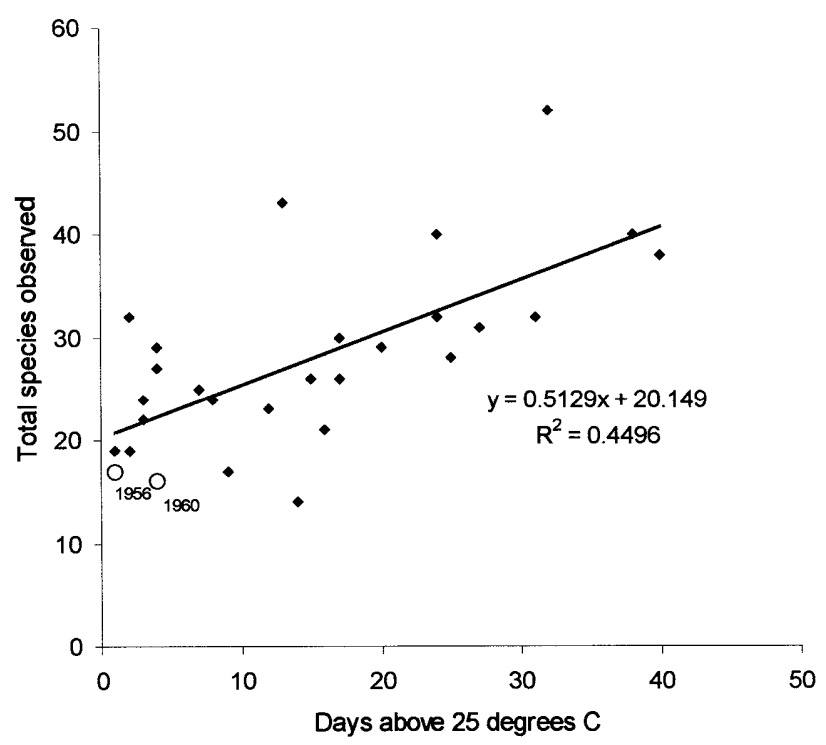

Fig. 3. Total species number of Heteroptera (less aquatic species) recorded for years between 1933 and 1999 in relation to the total number of days observed per year between June and September in which the maximum temperature exceeded $25^{\circ} \mathrm{C}$. The low species richness years of 1960 and 1956 are marked on the figure as open circles.

0.05 ) when this is allowed for by using $\log$-series $\alpha$ as a diversity measure which takes out any sample size effect.

\section{SPECIES DIVERSITY 1933-2000}

For direct comparison between years the effect of sample size (number of individuals) has to be removed. For this purpose we used $\alpha$ from the log-series distribution (Williams, 1947). This diversity parameter has been widely used for light-trap samples and shown to be superior to other commonly used statistics in robustness, independence of sample size and discriminant ability ( Taylor et al., 1976; Taylor, 1978; Kempton, 1979). The use of

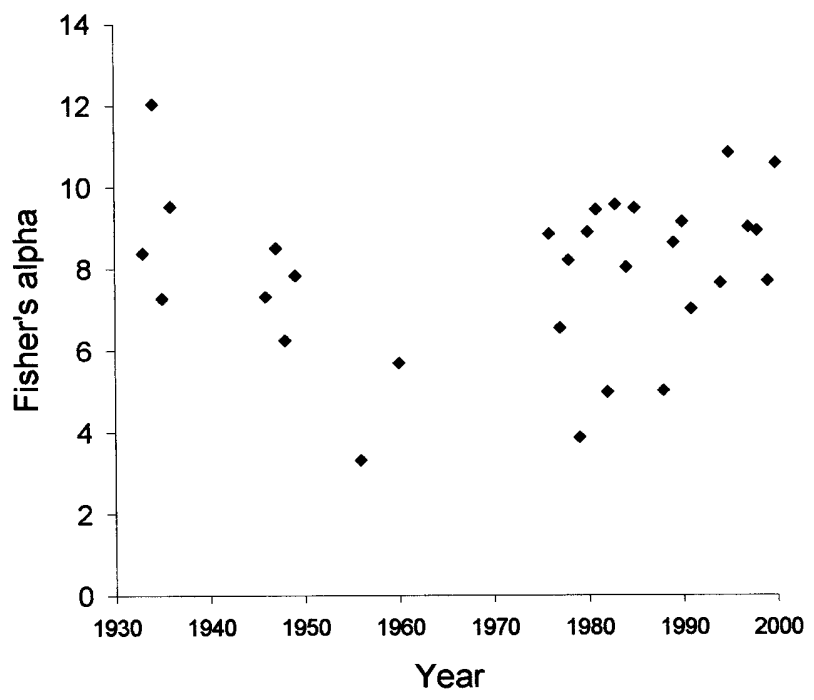

Fig 5. The temporal change in alpha diversity between 1933 and 2000 calculated for annual data collected using the Rothamsted light-traps.

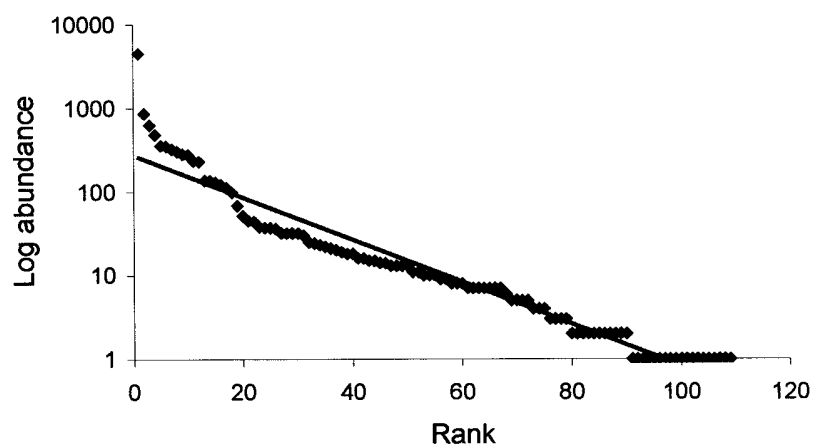

Fig 4. The rank-order $\log$ abundance plot for Heteroptera caught in the Rothamsted light-traps between 1933 and 2000.

this measure is further justified as the log abundance/rank plot approximates to a straight line (Fig. 4). There are a numbers of species that are more abundant than would be expected, as was found by Hodkinson \& Casson (2000) with Hemiptera collected in various ways in Sulawesi, Indonesia. As expected, the widely used Shannon Index did not discriminate for the higher diversities (May, 1975).

When the values of $\alpha$ for the catch in the various years are plotted a U-shaped pattern is produced (Fig. 5). By the 1990 s, diversity (as expressed by $\alpha$ ) was again as high as it was in the 1930s. The low point was in the period 1956-1970 ${ }^{1}$. Little reliance could be placed on these two points if it were not that the far more extensive data for macrolepidoptera showed the same trend with a large decrease in diversity between 1949 and 1960 (Taylor et al., 1978; Taylor, 1986). However apart from that the annual pattern of diversity is quite different between moths and Heteroptera.

It is interesting to note that the use of pesticides (insecticides and herbicides) at Rothamsted, was greatest between 1952 and 1974, and since 1985 none have been used on Barnfield. However, 1956 and 1960 had very few days with temperatures above $25^{\circ} \mathrm{C}$ (Fig. 3), so weather alone could account for the low species richness and, at these relatively small numbers, the index of diversity has wide confidence bounds.

\section{$\beta$-DIVERSITY WITH TIME IN THE DIFFERENT HABITATS}

$\beta$-diversity measures species turnover. In order to take account of changes of abundance as well as differences in species composition we used an index of difference (Bloom, 1981):

$$
I D_{12}=\frac{\sum_{j=1}^{s}\left|y_{1 j}-y_{2 j}\right|}{\sum_{j=1}^{s}\left(y_{1 j}+y_{2 j}\right)}
$$

where ID is the index of difference between periods 1 and $2, \mathrm{y}_{1 j}$ is the number of species $j$ in sample 1 and $s$ is the number of species present in both samples.

\footnotetext{
Only 11 specimens were found in the 1970 samples; in case this is an error the data were not used in any of the analyses .
} 
TABLE 1. Dissimilarity in the bug fauna between the years 1933-36 and subsequent 4-year groups of samples. A value of 1 indicates that the samples had no species in common. A value of zero would indicate that both periods held the same species in the same proportions.

\begin{tabular}{lcccccc}
\hline Habitat & $1946-49$ & $1976-79$ & $1980-83$ & $1984-89$ & $1990-95$ & $1997-00$ \\
\hline Water & 0.96 & 1.00 & 1.00 & 1.00 & 1.00 & 1.00 \\
Herbage & 0.37 & 0.81 & 0.89 & 0.67 & 0.65 & 0.93 \\
Trees & 0.68 & 0.72 & 0.74 & 0.64 & 0.73 & 0.69 \\
Grasses & 0.61 & 0.71 & 0.57 & 0.44 & 0.48 & 0.53 \\
Annuals & 0.47 & 0.49 & 0.37 & 0.35 & 0.58 & 0.31 \\
\hline
\end{tabular}

The index was used to compare community composition for four years of catches, with the period 1933-1936 being taken as the benchmark.

The change in community composition (the $\beta$-diversity) over the six-plus decades from the benchmark to the final four years (1997-2000) is 0.66. It is interesting to contrast this difference with the value of $\alpha$ (Fig. 5), which shows that $\alpha$-diversity in the two periods is approximately equivalent. Thus we conclude that although the $\alpha$-diversity is similar in magnitude between the benchmark and final period the actual make-up of the heteropteran fauna differs substantially.

The $\beta$-diversity for the comparison of a number of periods (each having four years of catch) with the 1930's benchmark can be calculated separately for five groups with different habitats: water, herbage (host plants being perennial herbs), trees, grasses and annuals (arable weeds) (Table 1). These generally show decreasing $\beta$-diversity in that order.

Catches of water bugs fell sharply in the 1940s and none were taken subsequently. This is a reflection of the loss of small ponds that has been widespread in Southern Britain (over the past century there has been a 75\% decrease in the number of ponds in Britain, Environment Agency, http://www.environment-agency.ov.uk/yourenv/ eff/water/213866/wetlands), and Southwood (1960) records the disappearance between 1936 and 1946 of one

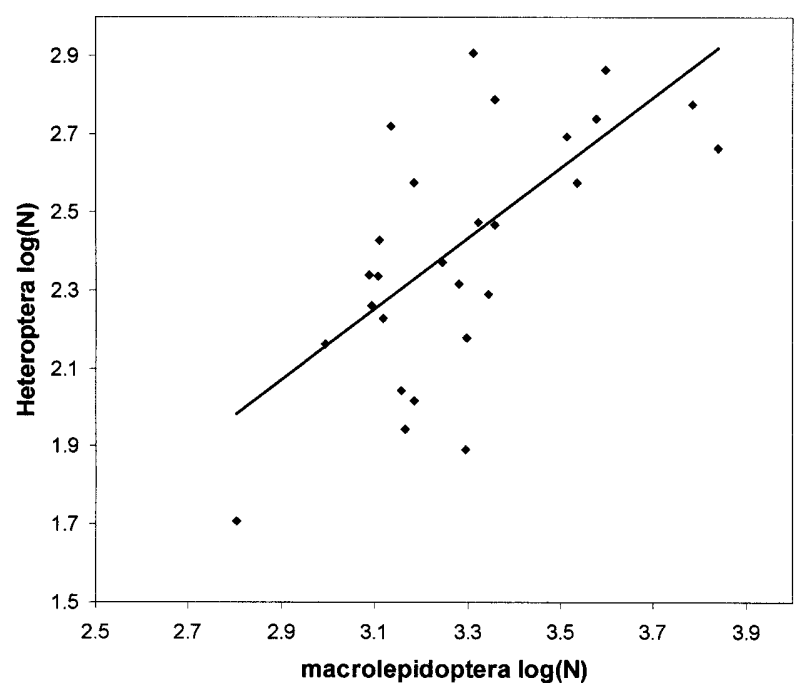

Fig 6. Regression of $\log ($ total abundance- N) of Heteroptera against macrolepidoptera from the Barnfield light-trap between 1933 and 2000. Slope $=0.90+/-0.23, r=0.61$. near the trap. The composition of the community on herbage altered little from the 1930 s to $1940 \mathrm{~s}$, but thereafter showed high values of $\beta$-diversity (i.e. changes in faunal make-up). This is likely to have reflected the impact of herbicide use from 1950-70 and the growth into trees of the shrub components in the Barnfield field margins, thus leading to an increase in shading. The lowest value in $\beta$-diversity (the least change) is found in the community associated with annuals, essentially weeds of arable crops, in particular Chenopodium album L. By and large the changes in $\beta$-diversity reflect changes in relative abundance, rather than turnover of species. The changes in relative abundance could be very striking: for example, 256 Orthops kalmii L. were caught in four years in the 1940s, and only 1 in eighteen years between 1976 and 2000. With regard to rarities, Deraeocoris scutellaris Fab. found in the 1940s (Southwood, 1950, 1960) has not been caught since, but one specimen of Deraeocoris olivaceus Fab. was trapped in 1995. This species was first recorded in Britain in 1951 and lives on hawthorn (Crataegus monogyna Jacq.).

\section{COMPARISON WITH LEPIDOPTERA}

When $\log$ (annual totals) of Heteroptera in the Barnfield trap are compared directly to the macrolepidoptera $\log$ (annual totals) for the same years there is a highly significant correlation $(\mathrm{r}=0.61, \mathrm{P}=0.00053)$ with a regression slope not significantly different from unity (Fig. 6). This suggests that environmental changes have affected the abundances of the two insect groups in a very similar way. Overall from 1933 to 2000 there was a significant decline in numbers of both groups but regressions of $\log$ abundance against year for the year classes 1933-1949 and 1960-2000 separately showed no significant trends. This confirms previously published results from the macrolepidoptera that emphasised the big decline in overall abundance that took place in the 1950 's, probably in response to the rapid agricultural intensification and the introduction of pesticides that took place at that time (Taylor, 1986).

In contrast to the picture of overall abundance, there is much less similarity in the changes in diversity between the two insect groups over time. The correlation between $\log$-series $\alpha$ for all the years in common is not significant and whereas there is evidence of an increase in Heteroptera diversity between 1960 and 2000, moth diversity continues to decline. 
The reason for the very similar changes in abundance between the Heteroptera and the macrolepidoptera since 1933 but the different responses in diversity is very interesting but not very easy to explain. It may be related to the reduced mobility of Heteroptera at low temperatures compared to Lepidoptera, allied to changes in the local environment in the immediate vicinity of the trap or there may be a larger scale change in overall diversity that is taking place. It is interesting to note that a recent review of the status of Heteroptera in the UK concluded that all changes in distribution since 1973 had mainly been increases (Kirby \& Stewart, 2001) whereas this certainly is not so for macrolepidoptera where there are many species declining and causing concern from a conservation perspective (Fox, 2001). Climate and land use change are probably the main agents for these larger scale changes in distribution and abundance of the two insects groups but local effects are also likely to play an important part.

ACKNOWLEDGEMENTS. Professor R. Plumb kindly made the records on pesticide use available to us, and we are also indebted to Dr. B.S. Nau for the data on catches in 1960, 1980 and 1985. One of us (TRES) is most grateful to the Leverhulme Trust for an Emeritus Fellowship. Rothamsted Research receives grant aid from the $\mathrm{BBSRC}$.

\section{REFERENCES}

Bloom S.A. 1981: Similarity indices in community studies: potential pitfalls. Mar. Ecol. Program. Series 5: 125-128.

Fox R. 2001: Butterflies and moths. In: Hawksworth D.L. (ed.): The Changing Wildlife of Great Britain and Ireland. The Systematics Association Special Volume Series 62, Taylor \& France, London, pp. 300-327.

HAWKSWORTH D.L. (ed.) 2001: The Changing Wildlife of Great Britain and Ireland. The Systematics Association Special Volume Series 62, Taylor \& France, London, pp. 300-327.

HODKINSON I.D. \& CASSON D.S. 2000: Patterns within patterns: abundance-size relationships within the Hemiptera of tropical rain forest or why phylogeny matters. Oikos 88: 509-514.

Intachat J. \& WorWoD I.P. 1999: Trap design for monitoring moth biodiversity in tropical rainforests. Bull. Entomol. Res. 89: 153-163.

KeMPTON R.A. 1979: The structure and species abundance and measurement of diversity. Biometrics 35: 307-321.

KirBY P. \& SteWart A.J.A. 2001: True bugs, leaf- and planthoppers, and their allies. In: Hawksworth D.L. (ed.): The Changing Wildlife of Great Britain and Ireland. The Systematics Association Special Volume Series 62, Taylor \& France, London, pp. 262-299.
MaY R.M. 1975: Patterns of species abundance and diversity. In: Cody M.L. \& Diamond J.M. (eds): Ecology and Evolution of Communities. Harvard University Press, Cambridge, Mass., pp. 81-120.

RILEY A.M. 1999: Macrolepidoptera at Rothamsted. Entomol. Rec. 111: 71-94.

SoutHwood T.R.E. 1950: Deraeocoris scutellaris F. (Hem.: Miridae) taken in light traps at Rothamsted, Hertfordshire. Entomol. Mon. Mag. 86: 78.

SoutHwoOD T.R.E. 1960: The flight activity of Heteroptera. Trans. R. Entomol. Soc. London 112: 173-220.

Southwood T.R.E. 1996: Natural communities: structure and dynamics. Phil. Trans. R. Soc. London B 351: 1113-1129.

TAYLOR L.R. 1963: Analysis of the effect of temperature on insects in flight. J. Animal Ecol. 32: 99-117.

TAYLOR L.R. 1978: Bates, Williams and Hutchinson - A variety of diversities. In: Mound L.A. \& Waloff N. (ed.): The Diversity of Insect Faunas. Blackwell Sci. Publ., Oxford, pp. 1-18.

TAYLOR L.R. 1986: Synoptic dynamics, migration and the Rothamsted Insect Survey. J. Animal Ecol. 55: 1-38.

TAYLOR L.R. \& FRENCH R.A. 1974: Effect of light trap design and illumination on samples of moths in an English woodland. Bull. Entomol. Res. 63: 583-594.

TAYlor L.R., French R.A. \& Wonwod I.P. 1978: The Rothamsted Insect Survey and the urbanization of land in Great Britain. In: Frankie G.W. \& Koehler C.S. (ed.): Perspectives in Urban Entomology. Academic Press, New York, pp. 31-65.

TAYLOR L.R., KEMPTON R.A. \& WorWOD I.P. 1976: Diversity statistics and the log-series model. J. Animal Ecol. 45: 255-272.

Thomas D.C. 1938: Report on the Hemiptera-Heteroptera taken in the light trap at Rothamsted Experimental Station, during the four years 1933-1936. Proc. R. Entomol. Soc. London 13: 19-24, Pts 1-3.

Williams C.B. 1939: An analysis of four years captures of insects in a light trap, Part 1: General survey; sex proportions; phenology; and time of flight. Trans. R. Entomol. Soc. London 89: 79-132.

Williams C.B. 1947: The logarithmic series and its application to biological problems. J. Ecol. 34: 253-272.

WoIwOD I.P. \& HaRRINGTON R. 1994: Flying in the face of change: The Rothamsted Insect Survey. In: Leigh R.A. \& Johnston A.E. (ed.): Long-term Experiments in Agricultural and Ecological Sciences. CAB International, Wallingford, pp. 321-342.

Wonwod I.P. \& Thomas J.A. 1993: The ecology of butterflies and moths at the landscape scale. In: Haines-Young R. (ed.): Landscape Ecology in Britain. University of Nottingham: IALE (UK)/Department of Geography, Nottingham, pp. 76-92.

Received February 27, 2003; revised July 3, 2003; accepted July 3, 2003 